\title{
Health, Human and Sustainable Development
}

\author{
Carla Aparecida Arena Ventura ${ }^{1}$, Marcela Jussara Miwa ${ }^{1}$, Márjore Serena Jorge ${ }^{1} \&$ Isabel Amélia Costa Mendes ${ }^{1}$ \\ ${ }^{1}$ University of São Paulo at Ribeirão Preto College of Nursing/WHO Collaborating Centre for Nursing Research \\ Development, Brazil \\ Correspondence: Isabel Amélia Costa Mendes, Ribeirão Preto College of Nursing/WHO Collaborating Centre for \\ Nursing Research Development, Avenida Bandeirantes, 3900 - Ribeirão Preto, SP, Brazil CEP 14040-902 Email: \\ iamendes@usp.br \\ This article was developed during the course "Global Health Diplomacy" offered by Isabel Amélia Costa Mendes and \\ Carla Aparecida Arena Ventura, from the Graduate Program on Fundamental Nursing and the Graduate Program on \\ Psychiatric Nursing.
}

Received: December 7, 2015

Accepted: December 21, $2015 \quad$ Available online: December 28, 2015

doi:10.11114/ijsss.v4i2.1235

URL: http://dx.doi.org/10.11114/ijsss.v4i2.1235

\begin{abstract}
The human right to development and human right to health are closely linked, and it is impossible to conceive the development process without the consolidation of the right to health. This article aims at discussing the potential connections between health, human and sustainable development in the context of increasing globalization.
\end{abstract}

Keywords: Right to health; Development; Human Right.

Conflict of interest: There is no conflict of interest

\section{Introduction}

\subsection{Health as a Human Right}

Since 1946 health is recognized as "one of the fundamental rights of every human being without distinction of race, religion, political belief, economic or social condition" (WHO, 2006). The essence of the right to health is oriented by the characteristics of a human right: universality, to all citizens without distinction; adequate progress, as once certain successes have been reached, they should be considered irreversible, implying in the adoption, by countries of measures for their protection; equality, which implies a distribution of human, technical and financial resources, based on both individual and collective needs, through positive measures to ensure that general health policies effectively reach all sectors of society (CANÇADO TRINDADE, 1991). However, the human rights, and therefore the right to health, are in a constant process of being rebuilt through social struggles (PIOVESAN, 2006).

In 1978, the right to health was reaffirmed during the Alma-Ata Conference. The Declaration of Alma-Ata emphasized an expanded health concept and pointed out the influence of social inequalities on health, highlighting the responsibility of governments for the health of their people (WHO, 1978). Accordingly, the governments should adopt a positive attitude to promote health and well-being of the population. When factors such as education, recreation, work, housing conditions and sanitation, among others, are developed with equity they directly affect the quality of life. The same document pointed to the importance of economic and social development to health as they reduce the differences regarding health status between developing and developed countries. However, the achievement of social and economic development is one of the international community greatest challenges, especially in finding ways to deal with globalization and its influence on health and development This article aims at discussing the potential connections between health, human and sustainable development in the context of increasing globalization.

\section{Discussion}

\subsection{Development and Globalization}

Development is a complex process and has been historically sought by the nations of the world. With the end of World War II and the creation of the United Nations (UN) in 1945 and the meeting in its midst of countries with different levels of development, the term "development" became an integral part of the work agendas of international organizations (SOARES, 1994; MARCOVITCH, 1994), based on a set of actions with the aim of reducing the gap 
between center and periphery, based on a demand for globalization that was more ethical and solidary.

With this view, important meetings to discuss development strategies were organized during the 1960s and 1970s, including the Bandung Conference (1955), in Indonesia; the Cairo Conference (1962); the First United Nations Conference on Trade and Development (1964); Algiers Conference (1973); The Lusaka Conference (1973); and the General Assemblies of the United Nations of 1974 and 1975 (FERNANDES, 2008).

In this sense, the African Charter on Human and Peoples' Rights of 1981 expressly recognized the right to development as a right of the human being in article 22, paragraphs 1 and 2, according to which:

All peoples shall have the right to their economic, social and cultural development with due regard to their freedom and identity and in the equal enjoyment of the common heritage of mankind. States shall have the duty, individually or collectively, to ensure the exercise of the right to development (OAU, 1981).

On December 4, 1986, the Declaration on the Right to Development defines in its first article the right to development as:

An inalienable human right by virtue of which every human person and all peoples are entitled to participate in, contribute to, and enjoy economic, social, cultural and political development, in which all human rights and fundamental freedoms can be fully realized (UN, 1986).

Despite the pioneering perspective of the African Charter on human and peoples' rights (1981) and the UN Declaration on the Right to Development in 1986, the recognition of the right to development as an unquestionable human right was consecrated definitively in the 1993 Vienna Conference on Human Right (UN, 1993).

The right to development should comprise three priority dimensions: a) the participation of the people, with the aid of democracy to guide the formulation of public policies, providing them with greater transparency and accountability; b) protection for basic needs of social justice set out in the Declaration on the Right to Development by the UN; and c) a need to adopt national policies and programs through international cooperation (SEN, 1999; PIOVESAN, 2006).

Accordingly, with regards to health, the degree of development and the socio-economic distribution patterns, the legal framework, the financial and geographical coverage of health public and private services at different levels, strategies adopted for the development and the adequacy of health care determine the specificities of the health sector in each country. Health systems are also influenced by other political and social macro-environmental factors, by the historical development of the sector and by the way each country organizes its services.

Nevertheless, when developing countries follow the logic of globalization, health can be negatively affected (BUSS, 2002). Globalization can bring some health benefits such as: to spread information and medical research, to facilitate trade of equipments and medicines (HELMAN, 2009:271); to facilitate the transfer of investment and technology (CORNIA, 2001); and to accelerate the economic development of poor countries (DOLLAR, 2001). However, despite these benefits, there are several negative impacts of globalization on health. Likewise, financial speculation, economic protectionism and trade barriers can harm the economies of poor countries, increasing foreign debts and social inequalities, reducing the social commitment of governments and undermining health programs and policies. Furthermore, due to the increment in migration flows, globalization can also increase the transmission of diseases, sex tourism, drug trafficking and conflicts as a result of economic and territorial disputes (BUSS, 2007).

According to Ibrahim (2013), globalization in African countries reinforced their economic marginalization, problems to consolidate democracy, leading them to lose their cultural identity.

In countries of South America, such as Bolivia and Argentina, globalization is hurting the culture of indigenous people. Although the governments recognize the value of traditional medicines from local communities, their development policies are destroying the environment: water pollution, logging and mineral extraction, deforestation, monoculture agriculture and overuse of pesticides. These factors reduced the areas for hunting and fishing as well as the areas of medicinal plants, affecting the quality of life of indigenous peoples, and making them more dependent on the biomedical system (HITA, 2014).

Akerman et al (2006) found that health organizations, which are uniquely based on scientific-technological knowledge defended by biomedicine, generate forms of production and consumption of health services with high costs, low impact on the population's health, strengthening barriers to health access as they place health needs on the sphere of private consumption.

In this scenario, development models and their intersection with health systems were put into question mainly due to the difficulty they faced to improve people's quality of life. In addition, doubts emerged about changes needed in the health fields, considering new ways of human development and aiming to improve people's lives (AKERMAN et al., 2006). Thereby, it is important to note that quality of life is paramount in local development. A developed city should not mean 
a large and populous city, but rather be a synonym of being a good city to inhabit, in which the population enjoys prosperity, education, security, health and personal growth prospects (MARTINELLI, JOYAL, 2004).

\subsection{Health, Human Development and the constant search for Sustainable Development}

To understand health and development connections, both as human rights, we must consider the concept of human development, which involves not only the economic dimension to evaluate the advancement of the population, but also social, cultural and political characteristics that influence life expectancy and are, therefore, directly linked to health. Thus, the main goal of human development is to extend the possibilities of peoples' choices, through the expansion of their capabilities and the scope of their activities, allowing them to enjoy a long, healthy, creative life with a lower illness rate (UNDP, 1990).

In 1990, the United Nations Development Program (UNDP, 1990) claimed that any development strategy should combine "accelerating economic growth, reducing absolute poverty and reducing absolute deterioration in the physical environment" (p. 61). However, in 2014, the same organization announced:

Despite recent progress in poverty reduction, more than 2.2 billion people are either near or living in multidimensional poverty. That means more than 15 percent of the world's people remain vulnerable to multidimensional poverty. At the same time, nearly 80 percent of the global population lack comprehensive social protection. About 12 percent (842 million) suffer from chronic hunger, and nearly half of all workers - more than 1.5 billion - are in informal or precarious employment. (UNDP, 2014: 2)

Furthermore, "more than 1.5 billion people live in countries affected by conflict" (UNDP, 2014:4) and there are many victims of other violent crimes. The World Health Organization, in its document on social determinants of health (WHO, 2011:30), called for a global action on these determinants and drew attention to the importance of the rich countries to be committed regarding the development of poorer countries, aiming at the achievement of a really sustainable development.

Sustainable development is more than preserving natural resources as it means to recognize that people are in the core of any development process (UN, 2012). According to the United Nations (2012), sustainable development is possible when it promotes inclusive and equitable economic growth, reduces inequalities, creates opportunities for all, and promotes sustainable management of natural resources and ecosystems that supports "economic, social and human development while facilitating ecosystem conservation" (p.1).

In this sense, to achieve this harmonious relationship between human beings, the environment and economic growth, the actions towards sustainable development become more consistent when conducted at local level, respecting the pace and wishes of local communities.

For such a development to be successful, local policies should be decentralized, intersectoral and flexible, working not only with the needs but also with the potential of the place and people. Furthermore, it should encourage creativity, innovation, individual and collective entrepreneurship, favoring the use of local resources to address local issues (AKERMAN, 2005). In the case of health, these aspects should contribute to greater use of simple, effective, cheap and affordable technologies.

For these reasons, local development has been pointed out by many authors and international organizations (UNDP, 2002) as a privileged field of action to drive resources, encourage citizenship, improve living conditions with healthier spaces and minimize health risks (CALAME, 2004). The expansion of possibilities and social and economic resources from localities represents one of the axes for the overcoming of inequalities and poverty (AKERMAN et al, 2006).

Thus, we consider that a better distribution of social and economic resources coupled with greater social participation in the design, implementation and evaluation of public health policies besides improve the quality of life, strengthens citizenship and stimulate human development.

More than simply maintaining labor-productive work, the connections between health and development encompass other aspects. According to Gadelha and Costa (2012), health influences the development in two main aspects: first, it is a right of citizenship; second, investment in health contributes to the economic sector, since health services generate jobs, income and investments in technological innovation. In turn, development stimulates human development, "involving the decrease in all sources of privation, by means of valuing people, which entails the need to review the State's role in the elaboration of social policies, such as health policies" (VENTURA, 2008).

\section{Conclusions}

The right to health is a fundamental human right (VENTURA et al, 2012), however, increasing social inequalities as a result of the globalization process as well as inefficient internal public policies hinder access to this right. Therefore, if 
we consider within the development framework, human and sustainable development as possibilities for people to have their freedom (SEN, 1999) to choose development regarding their own lives, any proposal for local or global development should be based on people's participation in the construction and implementation of public policies, including health policies.

In this perspective, an intelligent government in the social area is not a state of specific assistance based actions, but one with "state policies" of health, education, nutrition and culture able to achieve harmony between economic, social and environmental needs (KLIKSBERG, 1998).

In sum, the search for human and sustainable development is only possible if based on people's needs, enabling them to exercise their human rights. In this paper, we emphasized the importance of the right to health and its assurance by governments as a condition to achieve any level of human and sustainable development.

\section{References}

Akerman, M. (2005). Saúde e desenvolvimento local: princípios, conceitos, práticas e cooperação técnica. São Paulo: Hucitec.

Akerman, M. et al. (2006). Saúde e desenvolvimento: que conexões?. In: G.W. Campos; et al. (org.). Tratado de Saúde Coletiva. 2. ed. São Paulo: Hucitec; Rio de Janeiro: Ed Fiocruz.

Buss, P. M. (2002). Globalization and disease: in a unequal world, unequal health! Cadernos de Saúde Pública, 18(6), 1783-1788. http://dx.doi.org/10.1590/S0102-311X2002000600033

Buss, P. M. (2007). Globalização, pobreza e saúde. Ciência \& Saúde Coletiva, 12(6), 1575-1589. http://dx.doi.org/10.1590/S1413-81232007000600019

Calame, P. (2004). Repensar a gestão de nossas sociedades - 10 princípios para a governança, do local ao global. São Paulo: Pólis - Instituto de Estudos, Formação e Assessoria em Políticas Sociais.

Cançado Trindade, A.G. (1991). A proteção internacional dos direitos humanos: fundamentos jurídicos e instrumentos básicos. São Paulo: Saraiva, 1991.

Cornia, G. A. (2001). Globalization and health: results and options. Bulletin of the World Health Organization, 79(9), 834-841.

Dollar, D. (2001). Is globalization good for your health? Bulletin of the World Health Organization, 79(9), 827-833.

Fernandes, J. A. (2008). O direito ao desenvolvimento como um Direito Humano e prerrogativa dos Estados nas relações internacionais do século XXI. Revista Âmbito Jurídico, 50(XI).

Gadelha, C. A. G., \& Costa, L. S. (2012). Saúde e desenvolvimento no Brasil: avanços e desafios. Revista de Saúde Pública, 46(supl), 13-20. http://dx.doi.org/10.1590/S0034-89102012005000062

Helman, C. G. (2009). Migração, globalização e saúde. In: C. Helman. Cultura, saúde e doença. Porto Alegre: Artmed, 2009.

Hita, S. R. (2014). Salud, globalización e interculturalidad: una mirada antropológica a la situación de los pueblos indígenas de Sudamerica. Ciência \& Saúde Coletiva, 19(10), 4061-4069. http://dx.doi.org/10.1590/1413-812320141910.09372014

Ibrahim, A. A. (2013). The impact of globalization on Africa. International Journal of Humanities and Social Science, $3(15), 85-93$

Kliksberg, B. (1998). Repensando o Estado para o Desenvolvimento Social: superando dogmas e convencionalismos. São Paulo: Cortez.

Marcovitch, J. (1994). Competição, Cooperação e Competitividade. In: J. Marcovitch (ed.). Cooperação Internacional: estratégia e gestão. São Paulo: EDUSP.

Martinelli, D. P., \& Joyal, A. (2004). Desenvolvimento Local e o Papel das Pequenas e Médias Empresas. Barueri, São Paulo: Manole.

Organization of African Unity (1981). African Charter on Human Rights and Peoples' Rights, approved by a Ministry Conference of the Organization of African Unity. Available at: http://www.achpr.org/instruments/achpr/. Accessed on 15 January 2015.

Piovesan, F. (2006). Direitos Humanos e Justiça Internacional. São Paulo: Saraiva, 2006.

Sen, A. (1999). Development as freedom. New York: Alfred A. Knopf.

Soares, G. F. S. (1994). A Cooperação Técnica Internacional. In: J. Marcovitch (ed). Cooperação Internacional: 
estratégia e gestão. São Paulo: EDUSP, 165-218.

United Nations. (1986). Article 1 of the Declaration on the Right to Development, adopted by the Resolution no. 41/128 of the United Nation's General Assembly, 4 December 1986. Available at: http://www.un.org/documents/ga/res/41/a41r128.htm. Accessed on 15 April 2012.

United Nations. (1993). World Conference on Human Rights, Vienna, Austria. Available at: http://www.ohchr.org/EN/ABOUTUS/Pages/ViennaWC.aspx. Accessed on 15 January 2015.

United Nations. (2012). The future we want. Rio de Janeiro.

United Nations Development Programme. (1990). Human Development Report 1990. New York: Oxford University Press.

United Nations Development Programme. (2002). Human Development Report 2002; Deepening democracy in a fragmented world. New York: Oxford University Press.

United Nations Development Programme. (2011). Human Development Report 2011. Sustainability and Equity: A Better Future for All. Available at http://hdr.undp.org/en/content/human-development-report-2011. Accessed on 15 January 2015.

United Nations Development Programme. (2014). Human Development Report 2014. Sustaining Human Progress: reducing vulnerabilities and building resilience. Available at:http://hdr.undp.org/sites/default/files/hdr14-report-en-1.pdf. Accessed on 08 June 2015

Ventura, C. A. A. (2008). Health and human development: nursing and the human right to health in Brazil. Revista Gaúcha de Enfermagem, 29(1), 137-42.

Ventura, C. A. A., Mello, D. F., Andrade, R. D., \& Mendes, I. A. C. (2012). Aliança da Enfermagem com o usuário na defesa do SUS. Revista Brasileira de Enfermagem, Brasília, 65(6), 893-8. http://dx.doi.org/10.1590/S0034-71672012000600002

World Health Organization. (1978). Declaration of Alma-Ata.. Available at: http://www.who.int/publications/almaata_declaration_en.pdf. Accessed on 01 June 2015

World Health Organization. (2006). Constitution of World Health Organization - basics documents, Forty-fifth edition, Supplement. Available at:http://www.who.int/governance/eb/who_constitution_en.pdf. Accessed on 01 June 2015

World Health Organization. (2011). Closing the gap: policy into practice on social determinants of health - discussion paper. Rio de Janeiro.

\section{(cc) $\mathrm{BY}$}

This work is licensed under a Creative Commons Attribution 3.0 License. 